\title{
ENVIRONMENTAL IMPACT ASSESSMENT (EIA) OF ALTERNATIVE POTATO CROPPING SYSTEMS IN HAMADAN PROVINCE, IRAN
}

\author{
REZAEI, M. E. ${ }^{1}$ - BARMAKI, M. ${ }^{1 *}-$ VEISI, H. $^{2}$ \\ ${ }^{1}$ Department of Agronomy and Plant Breeding, University of Mohaghegh Ardabili, Ardabil \\ 1136756199, Iran (phone: +98-45-33510140; fax: +98-45-33512204) \\ ${ }^{2}$ Environmental Sciences Research Institute, Shahid Beheshti University, G.C., Evin, Tehran \\ 1983963113, Iran (phone: +98-21-22431971; fax: +98-21-22431971) \\ *Corresponding author \\ E-mail address: barmakimorteza@gmail.com \\ (Received $4^{\text {th }}$ Jul 2017; accepted $19^{\text {th }}$ Oct 2017)
}

\begin{abstract}
Potato is a staple food crop and a most important agricultural commodity in Hamadan Province, Iran. However, the province is facing such problems as water scarcity, nitrate pollution, and plant disease epidemics. This study explored the environmental impact assessment of potato cropping systems in Hamadan Province, Iran. To this purpose, 8 agri-environmental indicators were used for the EIAs of 4 potato cropping systems. These indicators included environmental potential risk indicator for pesticides, water use efficiency, nitrogen leaching, $\mathrm{CO}_{2}$ emission, energy use, biodiversity, golden potato cyst nematode, and land use. The 4 systems included traditional potato system, quasi-industrial potato system, industrial potato system, and government-promoted potato system and 5 groups of features were used to describe the mentioned systems: (1) irrigation methods; (2) seed placement; (3) machinery use; (4) agrochemical use; and (5) crops rotation. The results revealed that the traditional potato system had the lowest negative impact on the environment. Of the potato production systems studied, the government-promoted potato system, quasi-industrial potato system, and industrial potato system had successively fewer negative effects on the environment. Finally, some strategies are recommended for designing a new benchmark encompassing environmental thresholds using agri-environmental indicator scores and their relationships.
\end{abstract}

Keywords: sustainable food consumption, sustainability, Agri-Environmental Indicators (AEIs), agricultural inputs, irrigation methods

\section{Introduction}

Environmental impacts are increasingly resulted from agri-food supply chains (Sala et al., 2017). The agricultural sector accounts for about $11 \%$ of anthropogenic greenhouse gas emissions (Porter and Reay, 2016; Sellitto et al., 2017). In Iran, 3.8\% of total energy, more than $90 \%$ of groundwater, and $67.5 \%$ of surface water are consumed in this sector (Najafi Alamdari, 2016). Although alternative cultivation and improved agronomic practices are generally proposed for the mitigation of environmental impacts in agriculture (Tasca et al., 2017; Smith et al., 2017), to achieve a sustainable food system, Environmental Impact Assessment (EIA) as a multi-dimensional process of an intrinsically complex evaluation (Ramanathan, 2001) is essential. Thus, to effectively assess environmental impacts, multiple objectives based on local and global effects and effect-based indicators should be directly considered in the evaluation methods, while the means or practices should be selected by farmers (Repar et al., 2017; van der Werf and Petit, 2002). Consequently, AEIs were most comprehensively developed by the Organization for Economic Cooperation and Development (OECD) (OECD, 1999a, b, 
2001) for evaluating the environmental impacts. These indicators were defined by McRae et al. (2000) as a measure of the key environmental conditions, changes, or risks caused through agriculture or the related management practices utilized by producers. Therefore, agroecosystem is influenced by farming practices, the impacts of which can be estimated by AEIs at various decision-making levels. By employing them at the farm level, farmers can be environmentally friendly via an adaptation of their practices. Also, at the wider regional or national planning levels, policy decisions and assessments can be directed by AEIs (Glenn and Pannel, 1998). The 5 different topics of agri-environmental policies, including landscape, greenhouse gas emissions, agricultural nutrient loading, pesticide use, and species diversity were mentioned by Yli-Viikari et al. (2007). Based on the management of agricultural practices, numerous effects on the environment, such as the emissions of environmentally hazardous substances, ecological matter and energy turnover, soil productivity, and biodiversity can be assessed by AEIs. Yet, few indicators have been developed for each area by the scholars so far. Some indicators have been applied for models, such as those of the potential risks of nitrogen leaching (Lidon et al., 2013) and pesticide use (Pawelzik and Möller, 2014), as well as CO2 emission or global warming (He et al., 2016) and some like (EU), LU, WUE of irrigation, and EBZ have been directly measured (Brentrup et al., 2004; Geri et al., 2010; García-Feced et al., 2015; Larkin, 2016; He et al., 2016; Fandika et al., 2016).

The global production of potato crop is most dramatically increasing in the developing world. Until the early 1990s, most potatoes were being grown in the Russian Federation, Europe, and North America. Also, in Asia and Africa, potato production has been strongly increased (Birch et al., 2012). Due to this growing interest in potato, increasing the performance of this valuable food crop by decreasing its environmental impacts as future challenges is essential (Pawelzik and Möller, 2014). Accordingly, the potential of an integrated farming system of a moderate intensity was reported by Stavi et al. (2016) to sufficiently sustain environmental and ecosystem service qualities besides maintaining global food security. Notably, even the traditional systems persisting on the sustainability of high biodiversity have an advantage in some contexts (Hahn and Orrock, 2015; Uchida et al., 2016). Because of the political condition of the Iranian government, reliance on food imports will endanger food security. Potato cultivation is considered despite the water problems in Iran, because potatoes have a high nutritional content and can substitute for a large portion of wheat imports (DeFauw et al., 2012). In this regard, by using agri-environmental indicators, the current study aimed at addressing and comparing the environmental effects of the 4 mentioned systems to meet the environmental challenges of growing interests for potato production in Hamadan Province, Iran. To this goal, the features of the different potato cropping systems and their components were first described and then, their environmental impacts were assessed and compared based on the agricultural inputs used during the potato cultivation. Finally, some strategies were designed for the environmental thresholds as new benchmarks.

\section{Materials and methods}

\section{The study area}

This case study was conducted in Hamadan and Bahar Counties in Hamadan Province, Iran (Figure 1). Hamadan Province has a population of 1.7 million residents with 93935 farmers, who produce about $21 \%$ of the country's potato production 
(Anonymous, 2016). Hamadan region has an area of 1,949,400 ha and the farming area is $1,008,038$ ha $(51.7 \%$ ) (Ghasemi Mobtaker, 2010). The mean annual precipitation over the last 50 years has been $334.1 \mathrm{~mm}$. The region is characterized as having a cold rainy season between November and April and a warm dry period from May to October. The regional inter-annual rainfall variability is high, which strongly affects the yields based on a predominantly rain-fed agriculture (Veisi et al., 2015).

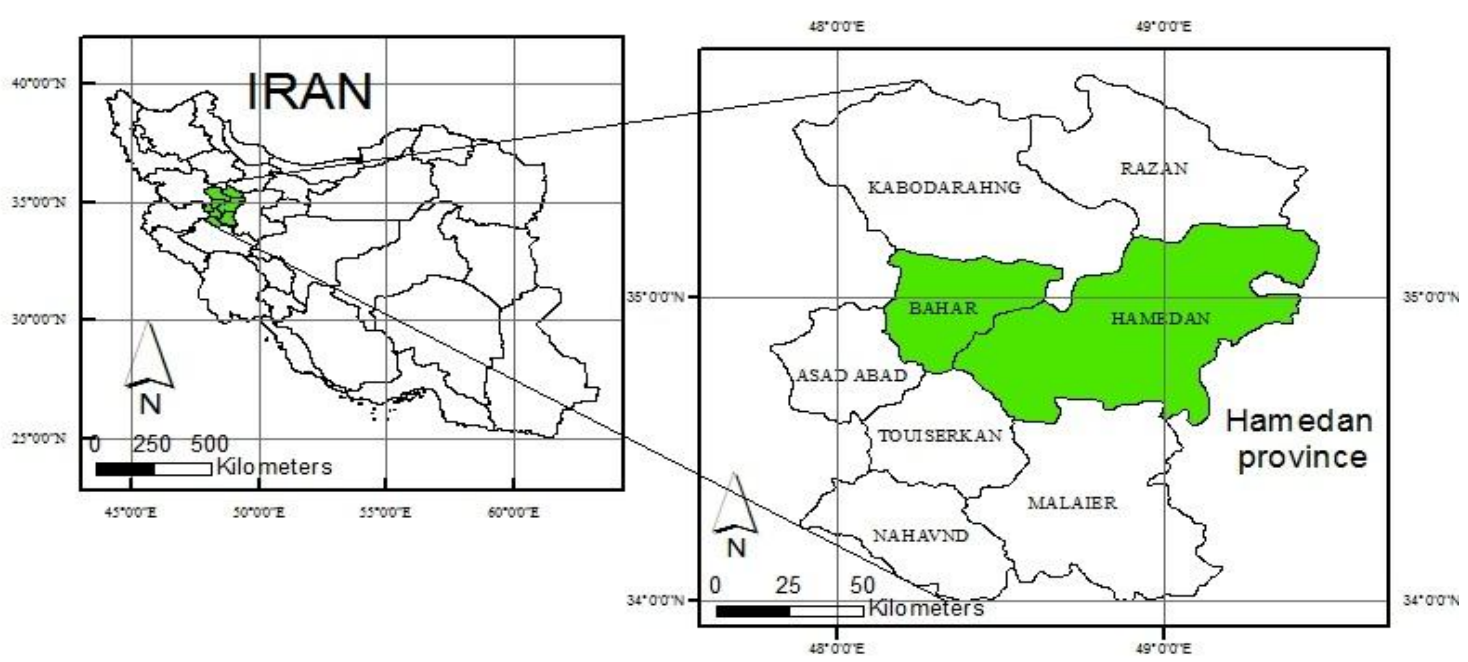

Figure 1. The study area location in Hamadan Province, Iran

\section{Description of the assessed potato production systems}

A potato cropping system refers to the management techniques, such as pest management, soil fertility strategies, and water source and irrigation practices, which are used on a particular field for a period of years. Hamadan-Bahar regions in Iran were selected for the practices of the potato cropping systems defined in this context. The regions have got a semiarid climate with a mean annual temperature of $11.3^{\circ} \mathrm{C}$ and mean annual precipitation of $324.5 \mathrm{~mm}$. The regional mean elevation is $2038 \mathrm{~m}$ above mean sea level (Akhavan et al., 2010). The major source of water supply for the agricultural sectors in the region is groundwater, which is also used for drinking and domestic and industrial activities. As a result, the groundwater level has continuously reduced in recent decades (Balali et al., 2011). In this research, the following 4 potato cropping systems were assessed by using AEIs during 2014-2015.

\section{Traditional Potato System (TPS)}

Historically, the potato cropping systems in the northwestern city of Hamadan typically included continuous potatoes and short-term rotations of 2 or 3 years with garlic (Allium sativum), cucumbers (Cucumis sativus), and vegetables, such as carrot (Daucus carota) and green beans (Phaseolus vulgaris). Many farms in the TPS had got a small size (0.5-1 ha). Rotations along with the extensive tillage and minimal crop residue returns during the potato phase of the rotation were the characteristics of this production system. Weeds were managed by hand and livestock manure was a key fertilizer in the system. Only in this system, the irrigation water was originated from 
surface water and irrigation practices were done via flood irrigation systems (Table 1). These data were collected from 25 farms.

\section{Quasi-Industrial Potato System (QIPS)}

In the Quasi-Industrial Potato System, the short-term crop rotations were simplified around cash crops, such as wheat (Triticum aestivum) and barley (Hordeum vulgare L.). The crop protection strategies of diseases and pests were mainly based on pesticides and the mechanical control of weeds. Dairy manure and chemical N, P, and K fertilizers were uniformly applied to the fields before planting. Water was harvested from deep and semi-deep wells and distributed through a system of pipes by pumping. In the QIPS, a sprinkler irrigation system was used for irrigation (Table 1). These data were collected from 36 farms.

\section{Industrial Potato System (IPS)}

In the Industrial Potato System, crop rotation was often removed and the crop management was intensive: high use of pesticides and fertilizers, high sowing rates and usual sowing dates, lack of a mechanical weeding, and weed control through the use of a number of active substances. Therefore, herbicide rates were higher than average in this system. The drip irrigation systems were installed after the potato seeds were planted. A thin-wall drip tape was placed on the soil surface at the center of the raised beds (Table 1). These data were collected from 21 farms.

Table 1. Comparison of the 4 potato cropping systems in Hamadan Province

\begin{tabular}{|c|c|c|c|c|}
\hline \multirow{2}{*}{ Attributes } & \multicolumn{4}{|c|}{ potato production systems } \\
\hline & TPS & QIPS & IPS & GPPS \\
\hline Irrigation methods & Flood irrigation & Sprinkler irrigation & Drop irrigation & Drop irrigation \\
\hline Seed placement & Flat ground & A row in the stack & $\begin{array}{l}\text { Two rows on the } \\
\text { stack }\end{array}$ & $\begin{array}{l}\text { Two rows on the } \\
\text { stack }\end{array}$ \\
\hline Use of machinery & $\begin{array}{l}\text { Substrate } \\
\text { preparation }\end{array}$ & $\begin{array}{l}\text { Substrate preparation, } \\
\text { Sowing, out tubers } \\
\text { from the soil }\end{array}$ & $\begin{array}{l}\text { Substrate preparation, } \\
\text { Sowing, out tubers } \\
\text { from the soil or } \\
\text { combine harvester }\end{array}$ & $\begin{array}{c}\text { Substrate } \\
\text { preparation, Sowing, } \\
\text { combine harvester }\end{array}$ \\
\hline $\begin{array}{l}\text { Use of mineral } \\
\text { fertilizers }\end{array}$ & Limited & Almost too much & Too much & Controlled \\
\hline The use of pesticides & Almost Limited & Almost too much & Too much & $\begin{array}{l}\text { The emphasis is on } \\
\text { organic pesticides }\end{array}$ \\
\hline Rotation & short-term & simplified & Without rotation & Recommended \\
\hline
\end{tabular}

\section{Government-Promoted Potato System (GPPS)}

A government project called as Government-Promoted Potato System (GPPS) aimed at reducing the environmental impact of potato production in the region from the early stages of implementation. The irrigation system used here was similar to that of the IPS except that water management was further emphasized in GPPS. An integrated control of pest management was developed by employing a number of various compatible control measures to minimize the harmful effects on the wider environment. In this method, water was mainly saved by drip irrigation. Furthermore, a limited use of fertilizers and pesticides was evaluated in this $4^{\text {th }}$ method (Table 1). This potato cropping system was applied to all the 5 farms under study. 


\section{Study methodology}

The method used in this research was based on 6 stages (Fig. 2).

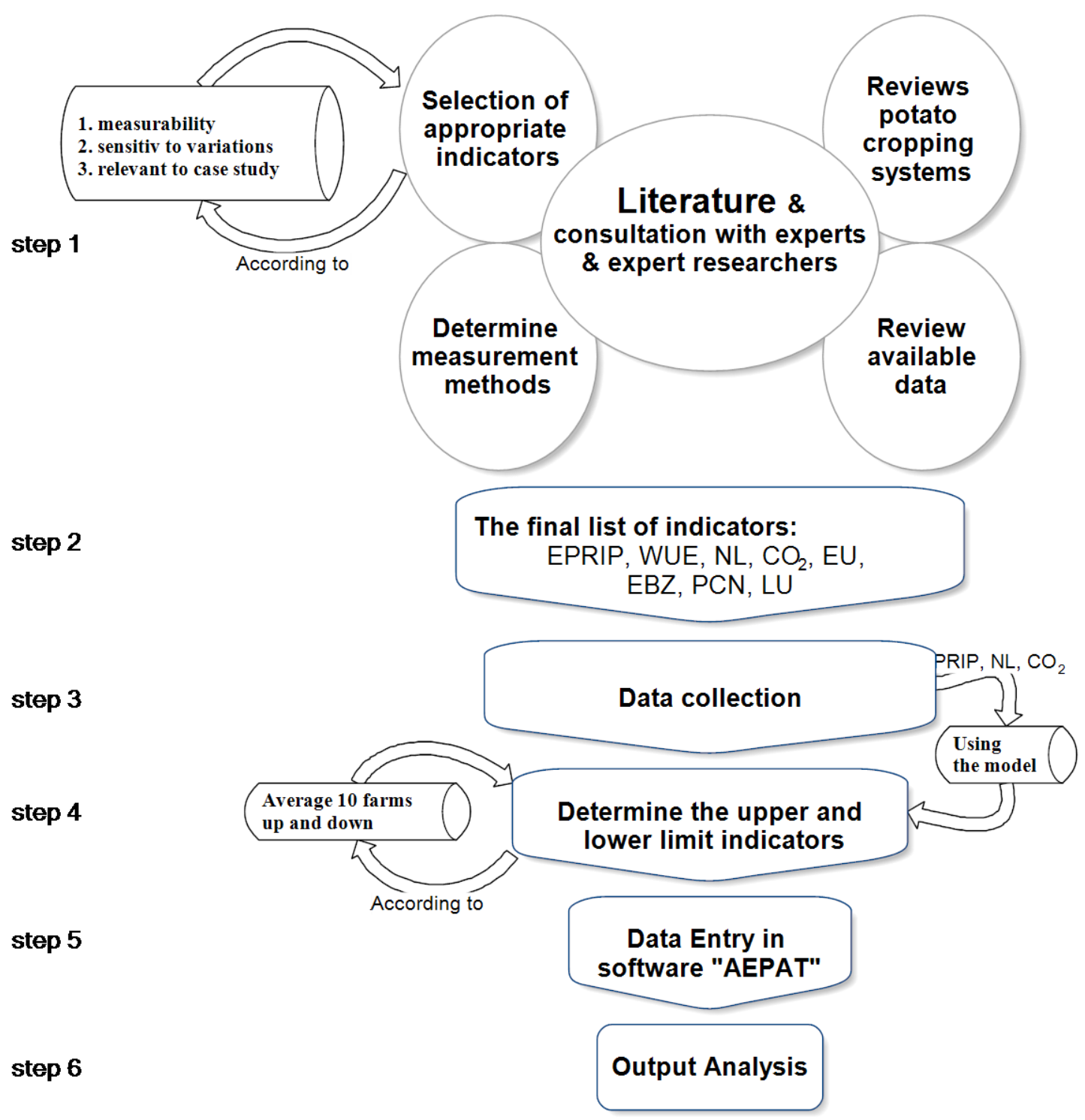

Figure 2. Study methodology framework for EIA of alternative potato cropping systems

The first stage included 4 sections that were almost preceded at the same time. The sections included reviews of the potato cropping systems and available data, selection of appropriate indicators, and determination of measurement methods. All the 4 sections were consulted with the relevant experts and expert researchers. In this step, the geographic and time scale boundaries, as well as the precise definitions of the study scenarios were discussed. In the 2nd step, the final lists of indicators and measurements were determined and an appropriate model was presented for measuring each indicator if necessary (The first 2 steps were adopted from the study of van Asselt et al., 2015). In step 3 , the required data and information were collected via a direct measurement. With 
the second-stage samples, a stage sampling method was used to select farms. The first stage involved determining the cropping systems on farms, and the second stage included selecting target farms in a square system. This approach ensured that the selected farms represent all farms. However, since the GPPS was only tested (experimentally) on 5 farms with good dispersal in the region, all farms under this cropping system were studied. In step 4, the average upper and lower limits of 10 farms were determined for each indicator and a total of $87 \mathrm{farms}$ were obtained. In step 5, the data were entered into "Agro-Ecosystem Performance Assessment Tool" (AEPAT) software to obtain each farm score and position. "AEPAT" software was used for assessing the agronomic and environmental performances of the management practices in agro-ecosystem experiments. This software is a computer program to assess the relative sustainability of management practices using agronomic and environmental data through performance-based indicators to derive the relative agro-ecosystem performance ranking for the functions and indicators (Liebig et al., 2004). Finally, "F" tests were employed to analyze the data and test the differences between the mentioned potato production cropping systems. When the results of the " $F$ " tests were significant, Tukey's HSD (honest significant difference) test was used to compare pairs of mean values (with $\mathrm{p}<0.05$ as the level for statistical significance). The EIA framework for the potato production cropping systems is presented in Figure 2.

\section{Agri-Environmental Indicators (AEIs)}

\section{Environmental Potential Risk Indicator for Pesticides (EPRIPs)}

As a most susceptible crop in arable crop rotations, potato is potentially influenced by some pests like aphids and nematodes, viruses, and diseases (Pawelzik and Möller, 2014). Potentially hazardous pesticides for soil, groundwater through leaching, surface water via drift and run-off, and air by volatilization can be evaluated by EPRIPs. Although some leaching information is provided by Groundwater Ubiquity Score (GUS), drift and run-off and volatilization are disregarded. The accepted EPRIP values are within a range of 1-625 points, which correspond to a number of risk classes indicating "None" to "Very large" risks to the environment by man (Pacini et al., 2009, Merante et al., 2015). Separate scores are given for varied environmental compartments by EPRIPs, which can be combined into a total score (Reus et al., 2002). In this work, the EPRIP variables were adopted from a previous study conducted by Ramezani and Heydari (2013) in the same area.

\section{Water Use Efficiency (WUE)}

Potato high sensitivity to drought stress is due to its shallow and sparse root system. Hence, the high yielding of this crop is dependent on irrigation (Birch et al., 2012). Rodriguez et al. (2015) found the water footprint of potato production reaching 324 $\mathrm{m}^{3} /$ ton and concluded that an average value of 65 liter of water was consumed by potato assuming that one potato was $0.2 \mathrm{~kg}$. Each plot yield $\left(\mathrm{t} \mathrm{ha}^{-1}\right)$ was recorded in each pick. WUE is potato effectiveness for using water during its complete period of growth. It is expressed as the ratio of total yield of marketable tuber to the total depth of water applied to the crop (Yaghi et al., 2013; Fandika et al., 2016). An effective rainfall during a complete period of growth is also incorporated in the total water. Marketable and nonmarketable tubers are $>55 \mathrm{~g}$ without any defects and $<55 \mathrm{~g}$ with defects, respectively. 
WUE ( $\mathrm{t} \mathrm{ha} \mathrm{mm}^{-1}$ ) is equal to CY/WA, where CY and WA indicate the total marketable tuber yield $\left(\mathrm{t} \mathrm{ha}^{-1}\right)$ and total depth of water applied $(\mathrm{mm})$, respectively.

\section{Nitrogen Leaching (NL)}

In autumn, potato leaves the highest nitrate $(\mathrm{N})$ amount after harvesting and is thus considered as a crop of highest residual nitrate level (Pawelzik and Möller, 2014). In this area, potato irrigation with groundwater is conducted with the simultaneous uses of fertilizers and agrochemicals. LEACHN model is a valid tool for assessing irrigation and $\mathrm{N}$ management effects on nitrate leaching (Lidon et al., 2013). Using Richards' equation, one-dimensional water flow can be described in unsaturated zones by this model. The main process of solute transport in the nitrogen module, including mineralization, nitrification, denitrification, and volatilization, is modeled by the convection-dispersion equation (Lidon et al., 2013). Nitrogen leaching amount was estimated via this model in this article.

\section{$\mathrm{CO}_{2}$ emission}

Atmospheric radiative forcing is caused by carbon dioxide $\left(\mathrm{CO}_{2}\right)$ as a part of greenhouse gases. Management highly determines the flux of these gases from agroecosystems. Radiative forcing can be lowered by agricultural management via enhancing soil organic carbon (Mosier et al., 2003; Liebig et al., 2005). $\mathrm{CO}_{2}$ cost of production was calculated by the Cool Farm Tool-Potato (CFT-Potato). The cost of producing 1 ton of potatoes by calculating $\mathrm{CO}_{2}$ equivalent amount is determined via CFT-Potato spreadsheet program (Sandaña and Kalazich, 2015; Haverkort et al., 2014). $\mathrm{CO}_{2}$ emission is equal to its total emission per ton of potatoes $\left(\mathrm{kg} \mathrm{CO}_{2}\right.$ eq $\left.\mathrm{t}^{-1}\right)$

\section{Energy Use (EU)}

Potato production is based on the Energy Uses (EUs) of seed potatoes, uses of fertilizers and agrochemicals, tractor operations, electricity (for irrigation), grading, storage, and store loading (Haverkort and Hillier, 2011; Haverkort et al., 2014). By calculating the primary EU factors, the data of fertilizer and pesticide productions were specified (Camargo et al., 2013). To this end, the potato production inputs, including electricity, irrigation water, farmyard manure, chemical fertilizers, pesticides, herbicides (biocides), fungicides, machinery, diesel fuel, and human labor were determined. Potato tubers were considered as the outputs. Upon calculating energy productivity, the input data computed per hectare were multiplied by the energy equivalent coefficient (Ghasemi Mobtaker et al., 2010; Mohammadi et al., 2008; Saad et al., 2016). Thus, EU was equal to potato tubers output $\left(\mathrm{kg} \mathrm{ha}^{-1}\right)$ divided by energy input $\left(\mathrm{MJ} \mathrm{ha}^{-1}\right)$.

\section{Biodiversity}

Certain forms of biodiversity loss are often caused by LU (Chen et al., 2016). Pest control and crop yield can be biologically promoted by the diverse strips of wildflower for farmland biodiversity (Tschumi et al., 2016). However, biodiversity in arable lands have been significantly declined by LU changes and simplification of cropping systems and chemical inputs for farming, while leading to the drastically reduced elements of Ecological Buffer Zones (EBZs), such as trees, wet zones, etc. (Bockstaller et al., 2011; Hole et al., 2005) Semi-natural habitats in the surrounding farms are highly enriched by 
biodiversity, especially in field edges (Lüscher et al., 2014). These habitats are mainly grasslands, shrub and agro-forestry areas, and the vegetation not used for crop production like hedgerows, buffer strips, field margins, and wood lots (García-Feced et al., 2015; Geri et al., 2010). Thus, EBZs are equal to the percentage of the semi-natural land surface.

\section{Golden Potato Cyst Nematode (PCN)}

The golden PCN (Globodera rostochiensis) is globally known as a most serious biotic constraint for potato production (Hajihassan et al., 2013). Several studies have addressed the relationship of reduced growth and yield parameters with the initial population density of potato cyst nematodes (Hajihassan et al., 2013; Greco and Moreno, 1992). To identify the suspiciously infested land area with nematodes based on symptoms like low growth and yellowing, the samples of nematode babies and eggs collected in June were examined in terms of numbers by using hand-binoculars and microscope (Gitty et al., 2001). Therefore, golden PCN was equal to the surface whit percentage of more than 15 babies or eggs per gram of soil.

\section{Land Use (LU)}

The functioning of ecosystems and natural resources can be positively or negatively influenced by LU (Taelman et al., 2016). To compare agricultural systems, LU productivity as the main component of land evaluation and supported LU planning must be determined (Huiyi, 2013; Sombroek, 1992). Assessment of LU productivity was done by calculating the total marketable potato weights with the diameters of more than $4.8 \mathrm{~cm}$ per $20 \mathrm{~m}$ of rows and converting them into the equivalent potato values of $\mathrm{Kg}$ per ha (Larkin, 2016; Brentrup et al., 2004). Therefore, $\mathrm{LU}$ was equal to potato tubers $\left(\mathrm{t} \mathrm{ha}^{-1}\right)$.

\section{Results and discussion}

\section{EPRIP}

The results analyzed by AEPAT software revealed the profound difference of TPS and IPS as the former provided management choices based on EPRIP with a value of 25 and a score of 0.9 , while the latter with a value of 103 and a score of 0.4 led to the mismanagement of pesticides used in the fields $(\mathrm{P}<0.01)$. In the TPS, mostly the farmers controlled weeds, pests, and diseases through cultivation techniques, while the main reason for the lowered score in IPS was related to the use of nematicidal compounds. On the other hand, a low difference was found between QIPS with a value of 78 and a score of 0.56 and GPPS with a value of 83 and a score of 0.52 , while both standing on the average (Table 2 and Figure 3). Chemical pesticide type is also very important. Several studies conducted in Iran and around the world, including those of Aghilinejad et al. (2008) and Koureas et al. (2012) have proven the positive relationship between health problems and exposure to pesticides. Soil fertility can be adversely affected by pesticide accumulation in the soil, which leads to the crop contamination (Komárek et al., 2010). 
Table 2. The environmental performances of the Traditional Potato System (TPS), QuasiIndustrial Potato System (QIPS), Industrial Potato System (IPS), and Government-promoted Potato System (GPPS)

\begin{tabular}{|c|c|c|c|c|c|c|c|c|}
\hline \multirow{2}{*}{ Indicators } & \multirow{2}{*}{$\begin{array}{c}\text { Abbrevi } \\
\text { ation }\end{array}$} & \multirow{2}{*}{ Unit } & \multirow{2}{*}{$\begin{array}{l}\text { Weigh } \\
\mathrm{t}(\%)\end{array}$} & \multicolumn{4}{|c|}{ Farming systems } & \multirow{2}{*}{$P$-value } \\
\hline & & & & TPS & QIPS & IPS & GPPS & \\
\hline $\begin{array}{l}\text { Environmental } \\
\text { Potential Risk } \\
\text { Indicator of } \\
\text { Pesticide Use }\end{array}$ & EPRIP & Score & 12.5 & $\begin{array}{c}25.54 \\
\pm 14\end{array}$ & $\begin{array}{c}78.31 \\
\pm 28\end{array}$ & $\begin{array}{c}103.43 \\
\pm 42\end{array}$ & $\begin{array}{c}83.40 \\
\pm 17\end{array}$ & $4 \mathrm{E}-13$ \\
\hline $\begin{array}{l}\text { Water use } \\
\text { efficiency }\end{array}$ & WUE & $\begin{array}{l}\mathrm{t} \mathrm{ha}^{-1} \\
\mathrm{~mm}^{-1}\end{array}$ & 12.5 & $\begin{array}{l}0.0234 \\
\pm 0.002\end{array}$ & $\begin{array}{l}0.0316 \\
\pm 0.004\end{array}$ & $\begin{array}{l}0.0420 \\
\pm 0.004\end{array}$ & $\begin{array}{l}0.0442 \\
\pm 0.004\end{array}$ & $8 \mathrm{E}-30$ \\
\hline Nitrogen leaching & NL & $\mathrm{kg} \mathrm{ha}^{-1}$ & 12.5 & $\begin{array}{c}35.67 \\
\pm 17\end{array}$ & $\begin{array}{l}49.80 \\
\pm 21\end{array}$ & $\begin{array}{l}44.56 \\
\pm 22\end{array}$ & $\begin{array}{l}36.76 \\
\pm 8.8\end{array}$ & 0.0497 \\
\hline $\mathrm{CO}_{2}$ emission & $\mathrm{CO}_{2}$ & $\underset{\mathrm{eq} \mathrm{t}^{-1}}{\mathrm{kgCO}}$ & 12.5 & $\begin{array}{l}40.01 \\
\pm 12\end{array}$ & $\begin{array}{l}52.12 \\
\pm 16\end{array}$ & $\begin{array}{l}54.86 \\
\pm 14\end{array}$ & $\begin{array}{c}46.09 \\
\pm 15\end{array}$ & 0.004 \\
\hline Energy use & EU & $\mathrm{kg} \mathrm{MJ}^{-1}$ & 12.5 & $\begin{array}{l}0.319 \\
\pm 0.04\end{array}$ & $\begin{array}{l}0.291 \\
\pm 0.03\end{array}$ & $\begin{array}{l}0.288 \\
\pm 0.03\end{array}$ & $\begin{array}{l}0.299 \\
\pm 0.01\end{array}$ & 0.007 \\
\hline $\begin{array}{l}\text { Biodiversity } \\
\text { (ecological buffer } \\
\text { zones) }\end{array}$ & EBZ & $\begin{array}{l}\text { Percent } \\
(\%)\end{array}$ & 12.5 & $\begin{array}{l}3.23 \\
\pm 0.9\end{array}$ & $\begin{array}{l}2.82 \\
\pm 0.8\end{array}$ & $\begin{array}{l}1.53 \\
\pm 0.7\end{array}$ & $\begin{array}{l}1.46 \\
\pm 0.4\end{array}$ & $4 \mathrm{E}-10$ \\
\hline $\begin{array}{l}\text { Potato golden cyst } \\
\text { nematode }\end{array}$ & $\mathrm{PCN}$ & $\begin{array}{l}\text { Percent } \\
(\%)\end{array}$ & 12.5 & $\begin{array}{l}0.008 \\
\pm 0.04\end{array}$ & $\begin{array}{c}0.141 \\
\pm 0.2\end{array}$ & $\begin{array}{c}0.203 \\
\pm 0.2\end{array}$ & $\begin{array}{c}0.100 \\
\pm 0.1\end{array}$ & 0.008 \\
\hline Land use & $\mathrm{LU}$ & $\mathrm{Kg} \mathrm{ha}^{-1}$ & 12.5 & $\begin{array}{c}30.14 \\
\pm 4.7\end{array}$ & $\begin{array}{c}33.79 \\
\pm 4.3\end{array}$ & $\begin{array}{c}34.86 \\
\pm 3.5\end{array}$ & $\begin{array}{c}34.33 \\
\pm 3.4\end{array}$ & 0.001 \\
\hline $\begin{array}{l}\text { Ecological } \\
\text { sustainability }\end{array}$ & Ec.Su & $\begin{array}{c}\text { Score } \\
(0-1)\end{array}$ & 100 & $\begin{array}{c}0.65 \\
\pm 0.10\end{array}$ & $\begin{array}{c}0.55 \\
\pm 0.14\end{array}$ & $\begin{array}{c}0.53 \\
\pm 0.14\end{array}$ & $\begin{array}{c}0.62 \\
\pm 0.08\end{array}$ & 0.01 \\
\hline
\end{tabular}

\section{Water Use Efficiency (WUE)}

Water Use Efficiency (WUE) was affected by the 4 cropping systems $(\mathrm{P}<0.01)$ (Table 2). Its indicator showed that GPSS with a production of 0.044 tons of tuber per hectare by consuming $10 \mathrm{~m}^{3} \mathrm{ha}^{-1}$ of water and gaining a score of 0.9 had a better behavior than the other systems. With the irrigation management, IPS and QIPS resulted in lower WUE values (0.042 and 0.0316 ton $\mathrm{ha}^{-1} \mathrm{~mm}^{-1}$, respectively) compared to GPSS, which in turn was lower than TPS $\left(0.023\right.$ ton $\left.\mathrm{ha}^{-1} \mathrm{~mm}^{-1}\right)$. In the drip irrigation, 79-88\% less water was used compared to GPSS and IPS, thus obtaining higher WUE compared to TPS surface irrigation. Drip irrigation has been shown to be an effective method for high potato yields (Wang et al., 2011; Onder et al., 2005). A 48-88\% increase in WUE with drip irrigation compared to surface and seepage irrigations was reported by Reyes-Cabrera et al. (2016) for potato production. Therefore, the scores obtained from the cropping systems of GPPS, IPS, QIPS, and TPS were equal to 0.9, $0.8,0.4$, and 0.1 , respectively. 


\section{Nitrogen Leaching $(N L)$}

The average Nitrogen Leaching (NL) indicator scores for GPPS, IPS, QIPS, and TPS were $0.77,0.65,0.57$, and 0.78 , respectively. In QIPS, NL was the highest (49.8 $\mathrm{kg} \mathrm{ha}^{-}$ ${ }^{1}$ ), whereas TPS (35.67 $\left.\mathrm{kg} \mathrm{ha}^{-1}\right)$ had the lowest NL ( $\left.\mathrm{p}<0.05\right)$. NL in GPPS $\left(36.76 \mathrm{~kg} \mathrm{ha}^{-}\right.$

${ }^{1}$ ) was lower than that of the IPS $\left(44.56 \mathrm{~kg} \mathrm{ha}^{-1}\right)$. In general, NL increases with a larger amount of irrigation water (Giletto and Echeverria, 2013) and a longer irrigation interval (Woli et al., 2016), while leading to an enhanced $\mathrm{N}$ rate since a more quantity of $\mathrm{N}$ is available in the soil for leaching (Cambouris et al., 2008). However, it shows a smaller amount with the clay soil compared to the lighter soils (Woli et al., 2016). QIPS and TPS used larger amounts of irrigation water, while QIPS and IPS had the greatest N rate uses. TPS and GPPS received relatively less amounts of nitrogen, whereas TPS had a clay soil. IPS had the longest irrigation interval, at least for the seasonal period.

\section{$\mathrm{CO}_{2}$ emissions per tons of potatoes}

Among the cropping systems, $\mathrm{CO}_{2}$ emission in IPS (54.86 $\left.\mathrm{kg} \mathrm{CO}_{2} \mathrm{eq}^{-1}\right)$ was the highest, which accounted for over $37 \%$ of that of the TPS $\left(40.01 \mathrm{~kg} \mathrm{CO}_{2} \mathrm{eq} \mathrm{t}^{-1}\right)$. QIPS (52.12 $\mathrm{kg} \mathrm{CO}_{2}$ eq $^{-1}$ ) and GPPS (46.09 $\mathrm{kg} \mathrm{CO}_{2}$ eq $^{-1}$ ) were ranked to be on the second and third positions. The previous studies conducted in the Netherlands (Haverkort and Hillier, 2011), southern Chile (Sandaña and Kalazich, 2015), and Iran (Pishgar-Komleh et al., 2012) represented $\mathrm{CO}_{2}$ emissions for potato production systems to be $77 \mathrm{~kg} \mathrm{CO}_{2}$ eq $\mathrm{t}^{-1}, 41-72 \mathrm{~kg} \mathrm{CO}_{2} \mathrm{eq} \mathrm{t}^{-1}$, and $992.88 \mathrm{~kg} \mathrm{CO}_{2} \mathrm{eq} \mathrm{ha}^{-1}$, respectively. Overall, the highest average score for $\mathrm{CO}_{2}$ emission per tons of potatoes was found in TPS (0.74), while GPPS, QIPS, and IPS scores were 0.63, 0.52, and 0.47, respectively (Fig. 3). The highest values of $\mathrm{CO}_{2}$ emission belonged to chemical fertilizer, diesel fuel, water for irrigation, and machinery.

\section{Energy Use (EU)}

Energy Use (EU) was highest in TPS $\left(0.319 \mathrm{~kg} \mathrm{Mj}^{-1}\right)$ due to the lower energy consumptions of chemical fertilizers (mainly nitrogen) and diesel fuel or electricity consumption for land preparation, sowing, and irrigation, whereas IPS had the lowest EU $\left(0.288 \mathrm{~kg} \mathrm{Mj}^{-1}\right)(\mathrm{p}<0.01)$. IPS consumed $11 \%, 4 \%$, and $1 \%$ higher energies to produce a potato unit compared to TPS, GPPS $\left(0.299 \mathrm{~kg} \mathrm{Mj}^{-1}\right)$, and QIPS $\left(0.291 \mathrm{~kg} \mathrm{Mj}^{-}\right.$ ${ }^{1}$ ), respectively. Overall, the highest energy use score was found in TPS (0.68), while those of the GPPS, QIPS, and IPS were 0.53, 0.47, and 0.44, respectively (Fig. 3).

The previous studies conducted in Ardabil Province in northern Iran (Mohammadi et al., 2008) and Hamadan (Rajabi Hamedani et al., 2011) and Esfahan provinces in the center of Iran (Pishgar-Komleh et al., 2012) demonstrated that the EUs for the mentioned potato production systems were $0.35,0.9-0.31$, and $0.37-0.59 \mathrm{~kg} \mathrm{Mj}^{-1}$, respectively. Pishgar-Komleh et al. (2012) showed that with an additional 1\% use of seed, water for irrigation, chemical fertilizer, and diesel fuel energies, the yields of potatoes raised to $0.36,0.42,0.12$, and $0.04 \%$, respectively. Rajabi Hamedani et al. (2011) showed that nitrogen fertilizer (39\%) had the highest consumption followed by diesel fuel (21\%) and seed (14.9\%). In their study, Park and Kremer (2017) concluded that EU was the most practical and useful indicator among all the 55 environmental sustainability indicators extracted from the extant literature. 


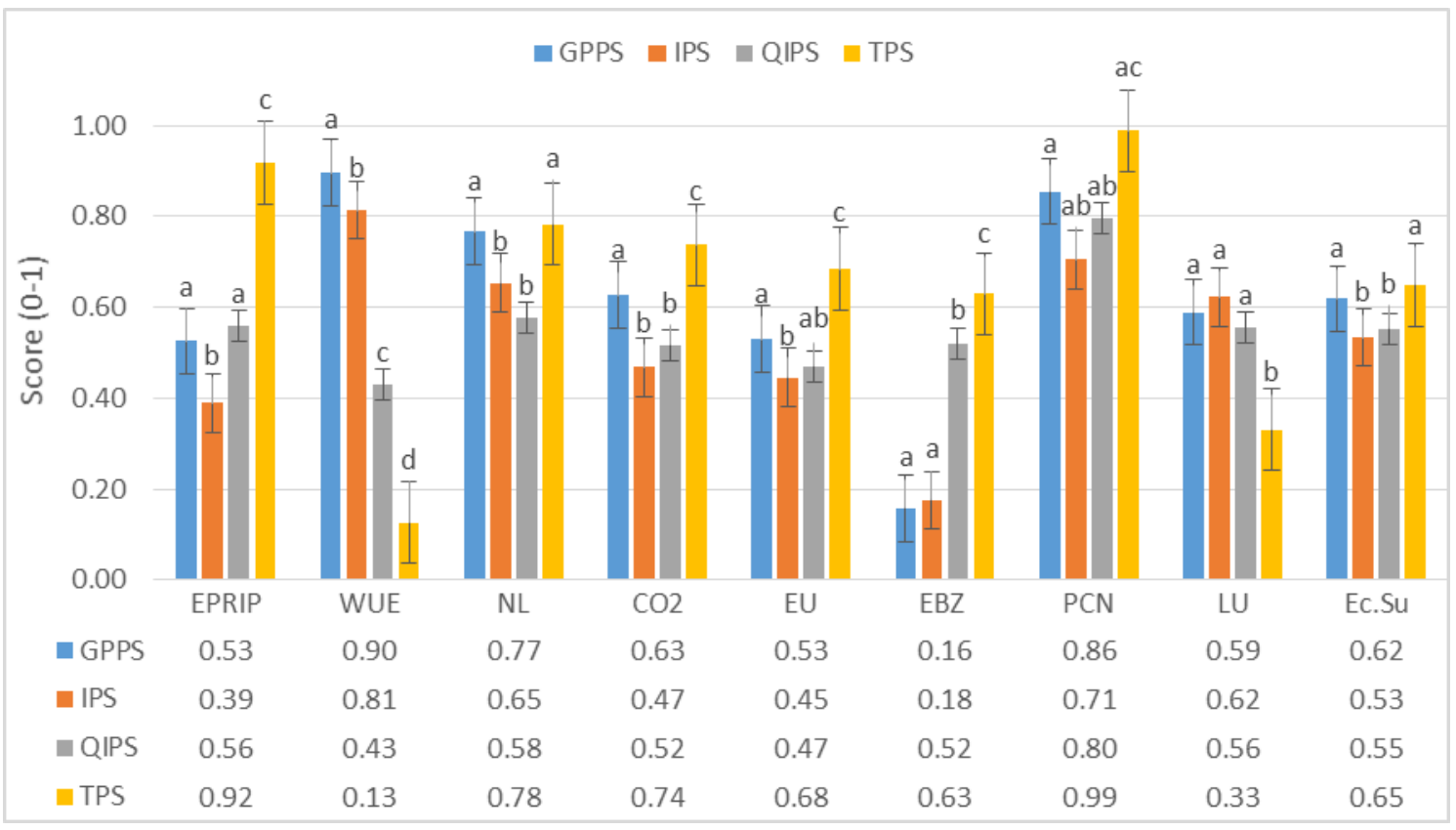

Figure 3. The environmental impacts of the Traditional Potato System (TPS), Quasi-Industrial Potato System (QIPS), Industrial Potato System (IPS), and Government-Promoted Potato System (GPPS); values with different letters indicate significant differences among the potato cropping systems at $5 \%$ by Tukey's HSD test.

\section{Ecological Buffer Zones (EBZ)}

Ecological Buffer Zones (EBZ) indicator represented that only $1.46 \%$ of the seminatural surface occurring in the GPPS had been conserved, while $98.54 \%$ of this system had been involved in agriculture and urban areas. However, 1.53, 2.82, and 3.32\% of the semi-natural surfaces occurring in the IPS, QTPS, and TPS had been conserved, respectively. Based on the Common Agricultural Policy (CAP) legislation (2014-2020), at least $5 \%$ of the arable lands holding for most farms with an arable area of larger than 15 hectares must be dedicated to the ecological areas mainly composed by semi-natural vegetation features (García-Feced et al., 2015). The rapid loss of semi-natural lands caused by advanced agriculture area has been proven (Liu et al., 2016). Overall, the highest EBZ score was found for TPS (0.63), while those of the QIPS, IPS, and GPPS were $0.52,0.18$, and 0.16 , respectively (Fig. 3).

\section{Golden Potato Cyst Nematode (PCN)}

In TPS, only $0.008 \%$ of the surface (in one of the surveyed potato fields) had more than 15 babies or eggs of golden Potato Cyst Nematode (PCN) (Globodera rostochiensis) per gram of soil, while $0.2 \%$ of the surface was affected by more than 15 babies or eggs of golden PCN per gram of soil in IPS. The nematode infection in GPPS $(0.1 \%$ of surface $)$ was slightly lower than that of the QIPS $(0.14 \%$ of surface $)(p<0.01)$. Currently, nematicides classified as organophosphates, carbamates, and soil fumigants are somewhat used for nematode control. The challenge to control nematode pests is, however, becoming more difficult as Class I red-band nematicides are progressively withdrawn from world markets (Fourie et al., 2016). For example, among the most rigorous and non-discriminative measures that can be taken to control soil-borne pests 
like plant-parasitic nematodes, soil fumigants have been already banned in many countries or will be banned in the near future (Vervoort et al., 2014). The management of nematode pests is rarely successful in the long term when single strategies, such as chemical control, host plant resistance, crop rotation, and/or other methods are applied (Fourie et al., 2016). In this regard, the highest score was found for TPS (0.99), while the scores of GPPS, QIPS, and IPS were $0.86,0.80$, and 0.71 , respectively (Fig. 3).

\section{Land Use (LU)}

Land Use (LU) for the yield of marketable potato tubers was the highest (34.86 $\mathrm{t}$ $\left.\mathrm{ha}^{-1}\right)$ in IPS, whereas TPS had the lowest LU $\left(30.14 \mathrm{t} \mathrm{ha}^{-1}\right)(\mathrm{p}<0.01)$, which accounted for over 14\% of that of the TPS based on GPPS. Overall, GPPS $\left(34.43 \mathrm{t} \mathrm{ha}^{-1}\right)$ and QIPS (33.79 $\mathrm{t} \mathrm{ha}^{-1}$ ) were ranked on the second and third places. The previous studies conducted in Ardabil Province in northern Iran (Mohammadi et al., 2008) and Hamadan (Rajabi Hamedani et al., 2011) and Esfahan provinces in central Iran (Khoshnevisan et al., 2014 ) showed the average yields of potato production farms to be 28,35 , and 23 tons per hectare for the above-mentioned systems, respectively. Regardless of whether significant differences were found between GPPS and IPS together with QIPS, the highest score was found iforn IPS (0.62), while the scores of GPPS, QIPS, and TPS were 0.59, 0.56, and 0.33, respectively (Figure 3).

\section{Ecological Sustainability (Ec. Su.)}

Generally, this study represented clear environmental benefits associated with a transition from IPS to GPPS. In particular, GPPS offered great potentials to decrease the use of high-risk pesticides and chemical fertilizers. There was also a more efficient use of irrigation water. Yet, TPS indicated a minimum impact on the environment. Although TPS made inefficient uses of water and land, it was less dependent on fertilizers and pesticides. Moreover, biodiversity was considered in this system. Among the cropping systems studied, the highest ecological sustainability score was obtained for TPS (0.65), which accounted for over $22 \%, 18 \%$, and $5 \%$ of those of the IPS (0.53), QIPS (0.55), and GPPS (0.62), respectively. However, no significant differences were found between GPPS with TPS and QIPS with IPS. Finally, it should be noted that in calculating the ecological sustainability score, an equal share was given to each indicator (12\%). In the previous studies, Böhringer and Jochem (2007) applied a selfrestraint weighting that was believed to be generally associated with subjective judgments, while He et al. (2016) used 8 weighing indicators between 0.15 and 0.09 . The self-restraint weighting was also confirmed by Singh et al. (2009).

\section{Conclusion}

The aim of the paper was to conduct an assessment of the environmental impacts of 4 different types of potato cropping systems in Hamadan Province, as well as comparing the variations of such impacts with the current programs of agri-environmental indicators. In this regard, 8 indicators, i.e., EPRIP, $\mathrm{CO}_{2}$ emissions, $\mathrm{N}$ leaching, ..., were used to measure the environmental performance. The results revealed that TPS had better environmental performance than GPPS, QIPS, and IPS. Among all, GPPS had the potential to reduce the environmental impacts by increasing the proportion of seminatural areas. Certain benefits of GPPS, such as a suitable rotation due to its role in 
controlling diseases like nematodes, reduction of indirect energy consumption and carbon dioxide emissions, and wisely management of soil and nutrients were evidenced. For instance, compared to the other systems, IPS that was being strongly expanded in the middle plain areas had lower environmental performance because of possessing the lower scores of EPRIP, EU, and $\mathrm{CO}_{2}$ emissions, thus needing fundamental changes due to being involved in reduced water availability. We should conclude that farmers and agronomists will find useful information in this article to reduce the negative agricultural impacts on the environment through better decisions and provision of more efficient and sustainable potato production systems. Based on methodology, a more precise analysis can be provided since the AEIs used here were drawn from several indicators, including the direct environmental indicators. Therefore, the environmental performances of different types of farms can be more comprehensively evaluated. In general, it was demonstrated that the differences in the environmental performance can be readily and potentially detected by applying AEI methodology to potato cropping systems and more broadly to other crops in a standardized way.

We recommend that the relationship between total 8 agri-environmental indicators be calculated by study in research farms. In this case, the minimum score of one indicator that cannot be compensated by sufficiently high score of others indicators can be considered as environmental thresholds. For example, if the EBZ is reduced of a certain amount, it will increase the use of pesticides and thus reduce the scores in the EPRIP, $\mathrm{EU}$, and $\mathrm{CO} 2$ emissions, but before this threshold it can be compensated by the increase in LU score. Also, achieve highest scores in treatments with optimal and acceptable yield can be considered as sustainability marker at the farm level. Accordingly, we have a early warning system because if the farm consumes higher irrigation water or energy consumption of the calculated amount in the above method, these farms need to review their management practices. Of course, some environmental health rules should be considered for indicators such as NL and EPRIP, regardless of desirable performance. Regarding access to irrigation water, which is the biggest problem in the study area, it is necessary to establish the environmental sustainability thresholds at the regional level by calculating the amount of allowable harvest water of the region. It is also necessary to carry out research and enforcement measures regarding the control of the potato crop extent in order to meet the domestic needs of the country and prevent the export of this crop. Its necessary that the export product selected to based on regional advantage and have maximum compliance with the regional climate.

Acknowledgements. We express our sincere thanks to University of Mohaghegh Ardabili for funding this research. We also thank Mr. Hazhir-Kamal and Mr. Akbari moein for their help in conducting the field survey

\section{REFERENCES}

[1] Aghilinejad, M., Mohammadi, S., Farshad, A. A. (2008): The effect of pesticides on farmers' health. - Medical Research 31(4): 327-331. (in Persian).

[2] Akhavan, S., Abedi-Koupai, J., Mousavi, S. F., Afyuni, M., Eslamian, S. S., Abbaspour, K. C. (2010): Application of SWAT model to investigate nitrate leaching in HamadanBahar Watershed, Iran, Agriculture. - Ecosystems and Environment 139: 675-688. 
[3] Anonymous (2016): Annual Agricultural Statistics. Ministry of Jihad-e-Agriculture of Iran. - http://www.maj.ir (in Persian).

[4] Balali, H., Khalilian, S., Viaggi, D., Bartolini, F., Ahmadian, M. (2011): Groundwater balance and conservation under different water pricing and agricultural policy scenarios: A case study of the Hamadan-Bahar plain. - Ecological Economics 70: 863-872.

[5] Birch, P. R. J., Bryan, G., Fenton, B., Gilroy, E. M., Hein, I., Jones, J. T., Prashar, A., Taylor, M. A., Torrance, L., Toth, I. K. (2012): Crops that feed the world 8: Potato: are the trends of increased global production sustainable? - Food Security 4: 477-508.

[6] Bockstaller, C., Lasserre-Joulin, F., Slezack-Deschaumes, S., Piutti, S., Villerd, J., Amiaud, B., Plantureux, S. (2011): Assessing biodiversity in arable farmland by means of indicators: an overview. - OCL 18(3): 137-44.

[7] Böhringer, C., Jochem, P. E. P. (2007): Measuring the immeasurable-A survey of sustainability indices. - Ecological Economics 63: 1-8.

[8] Brentrup, F., Küsters, J., Lammel, J., Barraclough, P., Kuhlmann, H. (2004): Environmental impact assessment of agricultural production systems using the life cycle assessment (LCA) methodology II. The application to $\mathrm{N}$ fertilizer use in winter wheat production systems. - Europ. J. Agronomy 20: 265-279.

[9] Camargo, G. G. T., Ryan, M. R., Richard, T. L. (2013): Energy Use and Greenhouse Gas Emissions from Crop Production Using the Farm Energy Analysis Tool. - BioScience 63(4): 263-273.

[10] Cambouris, A. N., Zebarth, B. J., Nolin, M. C., Laverdiere, M. R. (2008): Apparent fertilizer $\mathrm{N}$ recovery and residual soil nitrate under continuous potato cropping: effect of $\mathrm{N}$ fertilization rate and timing. - Canadian Journal of Soil Science 88: 813-825.

[11] Chen, D. M., Tucker, B., Badami, M. G., Ramankutty, N., Rhemtulla J. M. (2016): A multi-dimensional metric for facilitating sustainable food choices in campus cafeterias. Journal of Cleaner Production 135: 1351-1362.

[12] DeFauw S. L., He Z., Larkin R. P., Mansour S. A. (2012): Sustainable Potato Production and Global Food Security. - In: He Z., Larkin R., Honeycutt W. (eds.) Sustainable Potato Production: Global Case Studies. Springer, Dordrecht 3-19.

[13] Fandika, I. R., Kemp, P. D., Millner, J. P., Horne, D., Roskruge, N. (2016): Irrigation and nitrogen effects on tuber yield and water use efficiency of heritage and modern potato cultivars. - Agricultural Water Management 170: 148-157.

[14] Fourie, H., Ahuja, P., Lammers, J., Daneel, M. (2016): Brassicacea-based management strategies as an alternative to combat nematode pests: A synopsis. - Crop Protection 80: 21-41.

[15] García-Feced, C., Weissteiner, C. J., Baraldi, A., Paracchini, M. L., Maes, J., Zulian, G., Kempen, M., Elbersen, B., Pérez-Soba, M. (2015): Semi-natural vegetation in agricultural land: European map and links to ecosystem service supply. - Agron. Sustain. Dev. 35: 273-283.

[16] Geri, F., Amici, V., Rocchini, D. (2010): Human activity impact on the heterogeneity of a Mediterranean landscape. - Applied Geography 30: 370-379.

[17] Ghasemi Mobtaker, H., Keyhani, A., Mohammadi, A., Rafiee, S., Akram, A. (2010): Sensitivity analysis of energy inputs for barley production in Hamedan Province of Iran. Agriculture, Ecosystems and Environment 137: 367-372.

[18] Giletto, C.M., Echeverria, H. E. (2013): Nitrogen balance for potato crops in thesoutheast pampas region. - Argent. Nutr. Cycl. - Agroecosyst 95: 73-86.

[19] Gitty, M., Tanhamaafi, Z., Arjmandian, A., Pishevar, S. (2001): Occurrence of Potato Golden Cyst Nematode in Iran and its Distribution in Hamadan Province. - Agricultural Biotechnology 10: 53-61.

[20] Glenn, N. A., Pannell, D. J. (1998): The economics and application of sustainability indicators in agriculture. - In: Paper presented at the $42^{\text {nd }}$ Annual Conference of the Australian Agricultural and Resource Economics Society, Jan 19-21. University of New England, Armidale. 
[21] Greco, N., Moreno, L. I. (1992): Influence of Globodera reostochiensis on yield of summer, winter and spring sown potato in Chile. - Nematropica 22: 165-173.

[22] Hahn, P. G., Orrock, L. (2015): Land-use history alters contemporary insect herbivore community composition and decouples plant-herbivore relationships. - Journal of Animal Ecology 84: 745-754.

[23] Hajihassani, A., Ebrahimian, E., Hajihasani, M. (2013): Estimation of Yield Damage in Potato Caused by Iranian Population of Globodera rostochiensis with and without Aldicarb under Greenhouse Conditions. - International Journal of Agriculture and Biology 15(2): 352-356.

[24] Haverkort, A. J., Hillier, J. G. (2011): Cool farm tool-potato: model description and performance of four production systems. - Potato Research 54: 355-369.

[25] Haverkort, A. J., Sandaña, P., Kalazich, J. (2014): Yield Gaps and Ecological Footprints of Potato Production Systems in Chile. - Potato Research 57: 13-31.

[26] He, X., Qiao, Y., Liu, Y., Dendler, L., Yin, C., Martin, F. (2016): Environmental impact assessment of organic and conventional tomato production in urban greenhouses of Beijing city, China. - Journal of Cleaner Production 134: 251-258.

[27] Hole, D. G., Perkins, A. J., Wilson, J. D., Alexander, I. H., Grice, P. V., Evans, A. D. (2005): Does organic farming benefit biodiversity? - Biological Conservation 122: 113130.

[28] Huiyi, Z. H. U. (2013): Underlying motivation for land use change: A case study on the variation of agricultural factor productivity in Xinjiang, China. - Journal of Geographical Sciences 23(6): 1041-1051.

[29] Khoshnevisan, B., Rafiee, S., Omid, M., Mousazadeh, H., Rajaeifar M. A. (2014): Application of artificial neural networks for prediction of output energy and GHG emissions in potato production in Iran. - Agricultural Systems 123: 120-127.

[30] Komárek, M., Čadková, E., Chrastný, V., Bordas, F., Bollinger, J. C. (2010): Contamination of vineyard soils with fungicides: A review of environmental and toxicological aspect. - Environment International 36: 138-15.

[31] Koureas, M., Tsakalof, A., Tsatsakis, A., Hadjichristodoulou, C. (2012): Systematic review of biomonitoring studies to determine the association between exposure to organophosphorus and pyrethroid insecticides and human health outcomes. - Toxicology Letters 210: 155-168.

[32] Larkin, R. P. (2016): Impacts of biocontrol products on Rhizoctonia disease of potato and soil microbial communities, and their persistence in soil. - Crop Protection 90: 96-105.

[33] Lidon, A., Ramos, C., Ginestar, D., Contreras, W. (2013): Assessment of LEACHN and a simple compartmental model to simulate nitrogen dynamics in citrus orchards. Agricultural Water Management 121: 42- 53.

[34] Liebig, M. A., Miller, M.E., Varval, G. E., Doran, J. W., Hanson, J. D. (2004): AEPAT: Software for assessing agronomic and environmental performance of management practices in long-term agroecosystem experiments. - Agronomy Journal 96:109-115.

[35] Liebig, M. A., Morgan, J. A., Reeder, J. D., Ellert, B. H., Gollany, H. T., Schuman, G. E. (2005): Greenhouse gas contributions and mitigation potential of agricultural practices in northwestern USA and western Canada. - Soil \& Tillage Research 83: 25-52.

[36] Liu, F., Zhang, H., Qin, Y., Dong, J., Xu, E., Yang, Y., Zhang, G., Xiao, X. (2016): Seminatural areas of Tarim Basin in northwest China: Linkage to desertification. - Science of the Total Environment 573: 178-188.

[37] Lüscher, G., Jeanneret, P., Schneider, M. K., Turnbull, L. A., Arndorfer, M., Balázs, K., Báldi, A., Bailey, D., Choisis J. P., Elek, Z., Frank T., Friedel, J. K., Kainz, M., KovácsHostyánszki, A., Oschatz, M. L., Paoletti, M. G., Papaja-Hülsbergen, S., Sarthou J. P., Siebrecht, N., Wolfrum, S., Herzog, F. (2014): Responses of plants, earthworms, spiders and bees to geographic location, agricultural management and surrounding landscape in European arable fields. - Agriculture, Ecosystems and Environment 186: 124-134. 
[38] McRae, T., Smith, C.A.S. and Gregorich, L.J. (2000): Environmental sustainability of canadian agriculture: report of the agri-environmental indicator project. -Ottawa, Ontario: Agriculture and Agri-Food, Canada.

[39] Merante, P., Van Passel S., Pacini, C. (2015): Using agro-environmental models to design a sustainable benchmark for the sustainable value method. - Agricultural Systems 136: 113.

[40] Mohammadi, A., Tabatabaeefar, A., Shahan, S., Rafiee, S., Keyhani, A. (2008): Energy use and economical analysis of potato production in Iran a case study: Ardabil province. Energy Conversion and Management 49: 3566-3570.

[41] Mosier, A. R., Peterson, G. A., Sherrod, L. A. (2003): Mitigating net global warming potential $\left(\mathrm{CO}_{2}, \mathrm{CH}_{4}\right.$, and $\left.\mathrm{N}_{2} \mathrm{O}\right)$ in upland crop production. - In: Proceedings of the Third International Methane and Nitrous Oxide Mitigation Conference, China, Beijing, November 17-21.

[42] Najafi Alamdarlo, H. (2017): Water consumption, agriculture value added and carbon dioxide emission in Iran, environmental Kuznets curve hypothesis. - International Journal of Environmental Science and Technology 13(8): 2079-2090.

[43] OECD (1999a). Environmental indicators for agriculture. - In: Concepts and Framework, vol. 1. - OECD Press, Paris.

[44] OECD (1999b). Summary reports and recommendations covering specific agrienvironmental indicators. - In: Environmental indicators for agriculture, vol. 2 (Issues and Design), "The York workshop". - OECD Press, Paris.

[45] OECD (2001). Environmental indicators for agriculture. - In: Methods and results, vol. 3. - OECD Press, Paris

[46] Onder, S., Caliskan, M. E., Onder, D., Caliskan, S. (2005): Different irrigation methods and water stress effects on potato yield and yield components. - Agricultural Water Management 73: 73-86.

[47] Pacini, C., Lazzerini, G., Migliorini, P., Vazzana C. (2009): An Indicator-Based Framework to Evaluate Sustainability of Farming Systems: Review of Applications in Tuscany. - Italian Journal of Agronomy 1: 23-39.

[48] Park, K., Kremer, G. E. O. (2017): Text mining-based categorization and user perspective analysis of environmental sustainability indicators for manufacturing and service systems. - Ecological Indicators 72: 803-820.

[49] Pawelzik, E., Möller, K. (2014): Sustainable Potato Production Worldwide: the Challenge to Assess Conventional and Organic Production Systems. - Potato Research 57: 273-290.

[50] Pishgar-Komleh, S. H., Ghahderijani, M., Sefeedpari, P. (2012): Energy consumption and $\mathrm{CO}_{2}$ emissions analysis of potato production based on different farm size levels in Iran. Journal of Cleaner Production 33: 183-19.

[51] Porter, S., Reay, D. (2016): Addressing food supply chain and consumption inefficiencies: potential for climate change mitigation. - Regional Environmental Change 16: 2279-2290.

[52] Rajabi Hamedani, S., Shabani, Z., Rafiee, S. (2011): Energy inputs and crop yield relationship in potato production in Hamadan province of Iran. - Energy 36: 2367-2371.

[53] Ramanathan, R. (2001): A note on the use of the analytic hierarchy process for environmental impact assessment. - Journal of Environmental Management 63: 27-35.

[54] Ramezani, M. K., Heydari, A. (2013): Risk assessment of current-use insecticides and acaricides in Iran. - Pesticides Research Department, Institute of Plant Protection Research, Tehran.

[55] Repar, N., Jan, P., Dux, D., Nemecek, T., Doluschitz, R. (2017): Implementing farm-level environmental sustainability in environmental performance indicators: A combined global-local approach. - Journal of Cleaner Production 140: 692-704.

[56] Reus, J., Leendertse, P., Bockstaller, C., Fomsgaard, I., Gutsche, V., Lewis, K., Nilsson, C., Pussemier, L., Trevisan, M., van der Werf, H., Alfarroba, F., Blümel, S., Isart, J., McGrath, D., Seppälä, T. (2002): Comparison and evaluation of eight pesticide 
environmental risk indicators developed in Europe and recommendations for future use. Agriculture, Ecosystems and Environment 90: 177-187.

[57] Reyes-Cabrera, J., Zotarelli, L., Dukes, M. D., Rowland, D. L., Sargent, S. A. (2016): Soil moisture distribution under drip irrigation and seepage for potato production. Agricultural Water Management 169: 183-192.

[58] Rodriguez, C. I., Ruiz de Galarreta, V. A., Kruse, E. E. (2015): Analysis of water footprint of potato production in the pampean region of Argentina. - Journal of Cleaner Production 90: 91-96.

[59] Saad, A. A., Das, T. K., Rana, D. S., Sharma, A. R., Bhattacharyya, R., Lal, K. (2016): Energy auditing of a maize-wheat-greengram cropping system under conventional and conservation agriculture in irrigated north-western Indo-Gangetic Plains. - Energy 116: 293-305.

[60] Sala, S., Anton, A., McLaren, S. J., Notarnicola, B., Saouter, E., Sonesson, U. (2017): In quest of reducing the environmental impacts of food production and consumption. Journal of Cleaner Production 140: 387-398.

[61] Sandaña, P., Kalazich, J. (2015): Attainable CO2 emission of ware potatoes under high yield conditions in southern Chile. - American Journal of Potato Research 92: 318-325.

[62] Sellitto, M. A., Vial, L. A. M., Viegas, C. V. (2018): Critical success factors in Short Food Supply Chains: case studies with milk and dairy producers from Italy and Brazil. Journal of Cleaner Production 170: 1361-1368.

[63] Singh, R. K., Murty, H. R., Gupta, S. K., Dikshit, A. K. (2009): An overview of sustainability assessment methodologies. - Ecological Indicators 9: 189-212.

[64] Smith, P., Martino, D., Cai, Z., Gwary, D., Janzen, H., Kumar, P., McCarl, B., Ogle, S., O’Mara, F., Rice, C., Scholes, B., Sirotenko, O. (2007): Agriculture. - In: Metz, B., Davidson, O. R., Bosch, P. R., Dave, R., Meyer L. A. (eds.) Climate Change 2007: Mitigation. Contribution of Working Group III to the Fourth Assessment Report of the Intergovernmental Panel on Climate Change. - Cambridge University Press, Cambridge, United Kingdom and New York, USA 499-540.

[65] Sombroek, W. G. (1992): Land use planning and productive capacity assessment. - In: Anderson, J. R., de Haen C. (eds.) Public and private roles in agri-cultural development; proceedings of the twelfth agricultural sector symposium. - The World Bank, Washington, D. C. 171-179.

[66] Stavi, I., Bel, G., Zaady, E. (2016): Soil functions and ecosystem services in conventional, conservation, and integrated agricultural systems. - Agronomy for Sustainable Development 36: 32th.

[67] Taelman, S. E., Schaubroeck, T., De Meester S., Boone L., Dewulf, J. (2016): Accounting for land use in life cycle assessment: The value of NPP as a proxy indicator to assess land use impacts on ecosystems. - Science of the Total Environment 550: 143 156.

[68] Tasca, A. L., Nessi, N., Rigamont, L. (2017): Environmental sustainability of agri-food supply chains: An LCA comparison between two alternative forms of production and distribution of endive in northern Italy. - Journal of Cleaner Production 140(2): 725-741.

[69] Tschumi, M., Albrecht, M., Bärtschi C., Collatz J., Entling, M. H., Jacot, K. (2016): Perennial, species-rich wildflower strips enhance pest control and crop yield, Agriculture. - Ecosystems and Environment 220: 97-103.

[70] Uchida, K., Hiraiwa, M. K., Ushimaru, A. (2016): Plant and herbivorous insect diversity loss are greater than null model expectations due to land-use changes in agro-ecosystems. - Biological Conservation 201: 270-276.

[71] van Asselt, E. D., van Bussel, L. G. J., van Horne, P, van der Voet, H., van der Heijden, G. W. A. M., van der Fels-Klerx, H. J. (2015): Assessing the sustainability of egg production systems in The Netherlands. - Poultry Science 94 (8): 1742-1750. 
[72] van der Werf, H. M. G., Petit, J. (2002): Evaluation of the environmental impact of agriculture at the farm level: a comparison and analysis of 12 indicator-based methods, Agriculture. - Ecosystems and Environment 93: 131-145.

[73] Veisi, H., Rezaei, M.E., Khoshbakht, K., Kambuozia, J., Liaghati, H. (2015): An assessment of the impact of watershed programmes on agricultural sustainability in Hamedan province, Iran. - International Journal of Agricultural Sustainability 13: 308325.

[74] Vervoort, M. T. W., Vonk, J. A., Brolsma, K. M., Schütze, W., Quist, C. W., de Goede, R. G. M., Hoffland, E., Bakker, J., Mulder, C., Hallmann, J., Helder, J. (2014): Release of isothiocyanates does not explain the effects of biofumigation with Indian mustard cultivars on nematode assemblages. - Soil Biology \& Biochemistry 68: 200-207.

[75] Wang, F. X., Wu, X. X., Shock, C. C., Chu, L. Y., Gu. X. X., Xue, X. (2011): Effects of drip irrigation regimes on potato tuber yield and quality under plastic mulch in arid Northwestern China. - Field Crops Research 122: 78-84.

[76] Woli, P., Hoogenboom, G., Alva, A. (2016): Simulation of potato yield, nitrate leaching, and profit margins as influenced by irrigation and nitrogen management in different soils and production regions. - Agricultural Water Management 171: 120-130.

[77] Yaghi, T., Arslan, A., Naoum, F. (2013): Cucumber (Cucumis sativus, L.) water use efficiency (WUE) under plastic mulch and drip irrigation. - Agricultural Water Management 128: 149-157.

[78] Yli-Viikari, A., Hietala-Koivu, R., Huusela-Veistola, E., Hyvonen, T., Perala, P., Turtola, E. (2007): Evaluating agri-environmental indicators (AEIs) - Use and limitations of international indicators at national level. - Ecological Indicators 7: 150-163. 